\title{
EXCESS DIETARY METHIONINE AND PREGNANCY IN THE RAT
}

\author{
ANNA T. VIAU AND J. H. LEATHEM \\ Bureau of Biological Research, Rutgers University, \\ New Brunswick, New Jersey 08903, U.S.A.
}

(Received 25th August 1972)

Pregnancy maintenance in the rat is seriously impaired by diets containing less than $6 \%$ protein (Nelson \& Evans, 1953). Reproductive failure can also occur when a single amino acid is deleted from an otherwise complete diet (Niiyama, Kishi \& Inoue, 1970). While considerable attention has been given to pregnancy and undernutrition, relatively little research has involved the excess of single amino acids (Harper, Benevenga \& Wohlheuter, 1970). Kerr \& Waisman (1967) fed as much as 7\% phenylalanine in a normal diet to pregnant rats without affecting pregnancy. Intraperitoneal injections of leucine into pregnant rats on Days 6 to 9 caused fetal resorptions (Persaud, 1969). When fed, however, leucine at a $10 \%$ level in a $27 \%$ casein diet did not modify the pregnancy but the number of surviving litters was reduced when the leucine supplement was added to a $9 \%$ casein diet (Cohlan \& Stone, 1961). Methionine, which stimulates the growth of rabbit blastocysts, was shown to improve the maintenance of pregnancy when added to a protein-free diet at a $0.4 \%$ level (Kinzey, 1970). On the other hand, excess methionine modifies growth and development, can influence appetite (Leung \& Rogers, 1969) and causes subnormal fetal growth (Leathem, Oslapas \& Fisher, 1968). The present investigation gives further consideration to methionine.

Sprague-Dawley rats of $190 \mathrm{~g}$ body weight were mated and Day 1 of pregnancy was determined by the presence of spermatozoa in the vaginal lavage. On Day 1 , the pregnant rats were fed a semi-purified diet containing $18 \%$ or $6 \%$ casein (Allison, Wannemacher, Banks \& Wunner, 1964) with or without $4 \%( \pm)$ methionine supplement. The reduced food intake associated with excess methionine feeding (Roth \& Allison, 1949) necessitated caging of animals individually for measurement of food intake. The food intake of animals fed an unsupplemented diet was restricted to that of the methionine-fed rats ('paired feeding'). Pregnancy was evaluated on Day 20.

All rats given free access to the $18 \%$ casein diet maintained pregnancy and gained $12 \% \mathrm{~g}$ in body weight. On Day 20 , an average of eleven fetuses weighing $3.5 \mathrm{~g}$ was observed. Placental weight was $457 \mathrm{mg}$. The addition of $4 \%( \pm)$ methionine was associated with the maintenance of pregnancy in ten out of seventeen animals and a body-weight gain of $16 \mathrm{~g}$ was noted for the pregnant rats. Fetal number was normal but the average fetal weight was subnormal $(2.5 \mathrm{~g})$ and the placental weight was also subnormal. The influence of methionine was not due to the reduced food intake as the 'pair-fed' animals revealed primarily a limited body weight gain (Table 1 ). 
The free-feeding of a diet containing $6 \%$ casein during pregnancy provided adequate maintenance but did limit body weight as well as fetal- and placentalweight gain. A diet of $6 \%$ casein supplemented with $4 \%( \pm)$ methionine resulted in fetal resorption in all animals. Furthermore, the unsupplemented $6 \%$ casein diet failed to support pregnancy when 'pair fed', producing fetal resorptions between Days 18 and 20 .

Reproductive failure in rats fed a protein-free diet is due to a lack of ovarian hormones, since administration of $0.5 \mu \mathrm{g}$ oestrone and $4.0 \mathrm{mg}$ progesterone from Day 3 to Day 20 of gestation will maintain pregnancy in $100 \%$ of the animals (Nelson \& Evans, 1954). Similar steroid treatment to pregnant rats fed $6 \%$ casein with $4 \%( \pm)$ methionine and their 'pair-fed' controls proved equally effective. Nevertheless, a body-weight loss was incurred which exceeded that of the 'pair-fed' controls and both placental and fetal weights were subnormal in rats fed excess methionine.

Table 1. Dietary casein, excess methionine and rat pregnancy

\begin{tabular}{|c|c|c|c|c|c|c|}
\hline Diet & $\begin{array}{c}\text { No. of } \\
\text { rats } \\
\text { mated }\end{array}$ & $\begin{array}{c}\text { No. of } \\
\text { pregnant rats } \\
(\text { Day 20) }\end{array}$ & $\begin{array}{c}\text { Rat } \\
\text { body-wt } \\
\text { change } \\
(g)\end{array}$ & $\begin{array}{l}\text { No. of } \\
\text { fetuses }\end{array}$ & $\begin{array}{l}\text { Fetal wt } \\
(g)\end{array}$ & $\begin{array}{l}\text { Placental wt } \\
(\mathrm{mg})\end{array}$ \\
\hline $\begin{array}{l}18 \% \text { casein } \\
18 \% \text { casein }+4 \%( \pm) \text { methionine } \\
18 \% \text { casein, 'pair-fed' } \\
6 \% \text { casein } \\
6 \% \text { casein }+4 \%( \pm) \text { methionine } \\
6 \% \text { casein, 'pair-fed' } \\
6 \% \text { casein }+4 \%( \pm) \text { methionine* } \\
6 \% \text { casein, 'pair-fed"* }\end{array}$ & $\begin{array}{r}20 \\
17 \\
9 \\
7 \\
10 \\
8 \\
13 \\
8\end{array}$ & $\begin{array}{r}20 \\
10 \\
8 \\
7 \\
0 \\
0 \\
13 \\
8\end{array}$ & $\begin{array}{r}+123 \\
+16 \\
+53 \\
+27 \\
-40 \\
-14 \\
-15 \\
-3\end{array}$ & $\begin{array}{c}11 \cdot 1 \\
10 \cdot 1 \\
10 \cdot 3 \\
11 \cdot 1 \\
- \\
\overline{9} \cdot 5 \\
10 \cdot 2\end{array}$ & $\begin{array}{l}3 \cdot 5 \pm 0 \cdot 1 \dagger \\
2 \cdot 5 \pm 0 \cdot 1 \\
3 \cdot 6 \pm 0.1 \\
2 \cdot 7+0 \cdot 1 \\
\\
2 \cdot 1 \pm 0 \cdot 1 \\
2 \cdot 5 \pm 0.1\end{array}$ & $\begin{array}{l}457 \pm 12 \dagger \\
350 \pm 9 \\
440 \pm 11 \\
378 \pm 13 \\
330 \pm 10 \\
380 \pm 10\end{array}$ \\
\hline
\end{tabular}

* Oestrone $(0.5 \mu \mathrm{g})+$ progesterone $(4 \mathrm{mg})$ administered from Day 3 to Day 20.

$\dagger$ Values are means \pm standard error of the means.

The dietary excess of methionine prevented the increase in food intake associated with pregnancy and might be expected to modify the nitrogen balance (Roth \& Allison, 1949). Plasma amino acid balances would also be modified (Synderman, Holt, Norton \& Roitman, 1968) and would thus influence placental and fetal growth. In addition to the nutritional aspect, our data reveal that excess dietary methionine gives rise to inadequate ovarian steroid secretion but the mechanism underlying this chain of events is not understood.

Supported by Grant AM 04341 from the National Institute of Arthritis and Metabolic Diseases.

\section{REFERENCES}

Allison, J. B., Wannemacher, R. W., Jr, Banks, W. L., JR \& Wunner, W. H. (1964) The magnitude and significance of the protein reserves in rats fed at various levels of nitrogen. 7. Nutr. 84, 383.

Cohlan, S. Q. \& Stone, S. M. (1961) Effects of dietary and intraperitoneal excess of l-lysine and l-leucine on rat pregnancy and offspring. 7. Nutr. 74, 93.

Harper, A. E., Benevenga, N. J. \& Wohlheuter, R. M. (1970) Effects of ingestion of disproportionate amounts of amino acids. Physiol. Rev. 50, 428. 
KerR, G. R. \& Waisman, H. A. (1967) Dietary induction of hyperphenylalaninemia in the rat. $\mathcal{J}$. Nutr. 92, 10.

KINZEY, W. G. (1970) Maintenance of pregnancy in protein deficient rats with dietary supplements of methionine. Proc. Soc. exp. Biol. Med. 133, 449.

Leathem, J. H., Oslapas, R. \& Fisher, C. J. (1968) Protein nutrition and the biochemical composition of the uterus. Fert. Steril. 19, 206.

LEUNG, P. \& Rogers, Q.R. (1969) Food intake: regulation by plasma amino acid pattern. Life Sci. 8, 1.

Nelson, M. M. \& Evans, H. M. (1953) Relation of dietary protein level to reproduction in the rat. $\mathcal{J}$. Nutr. 51, 71.

Nelson, M. M. \& Evans H. M. (1954) Maintenance of pregnancy in the absence of dietary protein with estrone and progesterone. Endocrinology, 55, 543.

Niryama, Y., Kishi, K. \& INOUe, G. (1970) Effect of ovarian steroids on maintenance of pregnancy in rats fed diets devoid of one essential amino acid. J. Nutr. 100, 1461.

Persaud, T. V. N. (1969) Developmental abnormalities in the rat induced by the amino acid leucine. Naturwissenschaften, 56, 37.

Roth, J. S. \& Allison, J. B. (1949) The effect of feeding excess glycine, l-arginine and dl-methionine to rats on a casein diet. Proc. Soc. exp. Biol. Med. 70, 327.

Synderman, S. E., Holt, L. E., Norton, P. M. \& Rortman, E. (1968) Effect of high and low intakes of individual amino acids on the plasma aminogram. In: Protein Nutrition and Free Amino Acid Patterns, p. 19. Ed. J. H. Leathem. Rutgers University Press, New Brunswick, N.J. 